\title{
Determination of Selected Essential and Non-essential Metals in the Stems and Leaves of Rhamnus prinoides (Gesho)
}

\author{
Ararso Nagari * and Alemayehu Abebaw
}

Department of Chemistry, Ambo University, PO Box: 19, Ambo, Ethiopia

\begin{tabular}{|c|c|}
\hline Abstract & Article Information \\
\hline \multirow{7}{*}{ 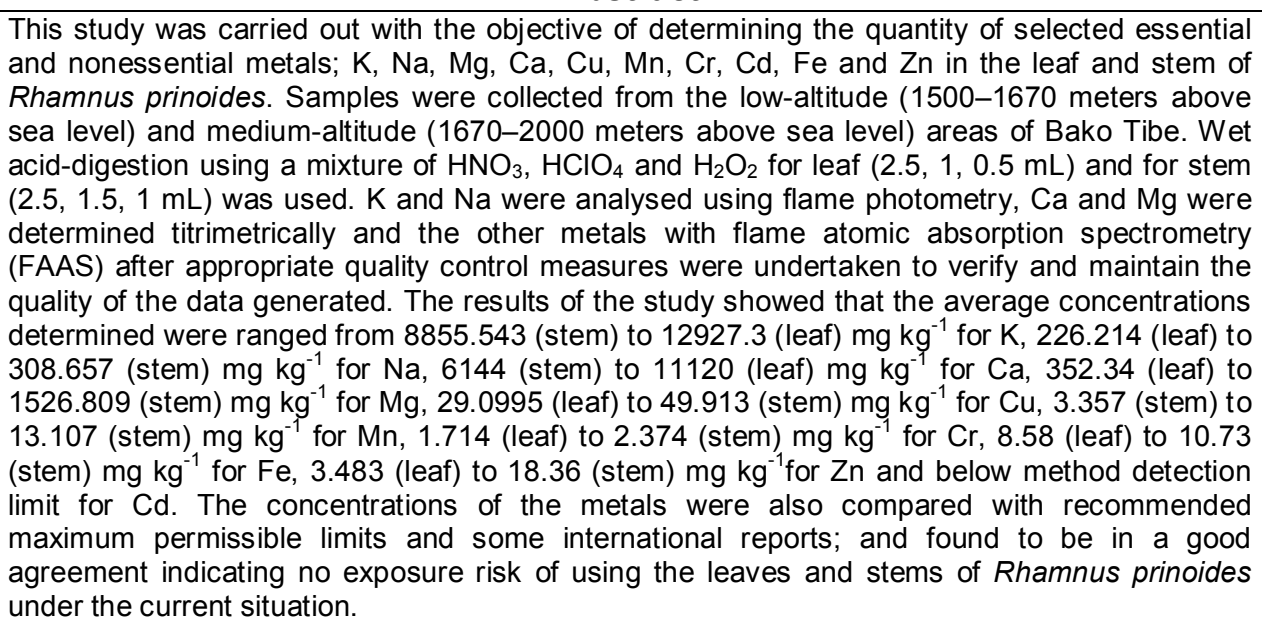 } & Article History: \\
\hline & $\begin{array}{ll}\text { Received } & : 15-09-2013 \\
\text { Revised } & : 24-12-2013 \\
\text { Accepted } & : 26-12-2013\end{array}$ \\
\hline & ds: \\
\hline & $\begin{array}{l}\text { ial metals } \\
\text { sential metals } \\
\text { us prinoides' }\end{array}$ \\
\hline & ${ }^{*}$ Corresponding Author: \\
\hline & Ararso Nagari \\
\hline & \\
\hline
\end{tabular}

\section{INTRODUCTION}

Rhamnus prinoides L'Herit, common name dogwood, Amharic name Gesho, family Rhamnaceae, is a wide spread plant species in East, Central and South African countries. It is a native plant to Ethiopia, Botswana, Eritrea, Lesotho, Namibia, South Africa, Swaziland, Uganda and exotic to Kenya. It also occurs in Cameroon, Sudan and Angola. The African dogwood, R. prinoides (Rhamnaceae) is a dense shrub or a tree that grows up to $6 \mathrm{~m}$ high (Berhanu and Teshome, 1995; Hailemichael et al., 2007; Afewerk and Chandravanshi, 2012).

The Gesho plant ( $R$. prinoides), which is different from hop (Humulus lupulus) is widely cultivated in Ethiopia and is available dried in the local market (Haimanot, 2011); the leaves and stems of this plant are used to impart the characteristic bitter flavour to domestically brewed beverages known as Tella and Tej and it is estimated that well over 5 million people consume these beverages daily (Berhanu and Teshome, 1995). The leaves and steams of Gesho are indispensable ingredients in the making of these traditional fermented beverages. It has been reported that the plant regulates the microflora responsible for the fermentation process. It plays a major role to suppress certain bacteria during the fermentation process (Hailemichael et al., 2007). It is also a valuable cash crop; leaves/twigs or stems are used by most of individuals in the country.

The Rhamnus prinoides L'Herit is also used as traditional medicine. In some African countries its leaf is used for the treatment of the diseases/disorders like stomach complications, joint pain, fever, diarrhea, common cold, malaria, body weakness, appetizer and pneumonia, sprains, gonorrhea, colic, rheumatism and ringworm infections (Berhanu and Teshome, 1995; Hailemichael et al., 2007). Specifically, in Southern Africa, the chief use of the tree is for magic; it is widely used as a protective charm toward off lightning and evil influences from homes and crops (Berhanu and Teshome, 1995; Hailemichael et al., 2007).

It is also known that the source of mineral nutrients for human being is mostly plant materials consumed in the form of drinks, food or medicine. So, since $R$. prinoides is one of the main constitutes of traditional drinks and also used as traditional medicines (serve to cure different diseases for human being and domestic animals), the knowledge of their mineral content is very useful. Thus, it is very important to assess the essential, non-essential and toxic mineral nutrients that can be accumulated in the 
Ararso Nagari and Alemayehu Abebaw

stated plant species so as to address the individual daily intake of mineral nutrients.

The objectives of the study were to: (i) optimize digestion procedure for the stem and leaf of Gesho samples to determine mineral contents by flame photometry and FAAS, (ii) determine the amounts of essential and non-essential metals in stem and leaf of the plant, (iii) compare the amounts of essential and nonessential metals in stem and leaf of the plant within the lowland and medium altitude, as well as between the lowland and medium altitude, and (iv) compare the amounts of essential and non-essential metals in stem and leaf of the plant with the literature values. For which the samples of the leaves and stems of Rhamnus prinoides were collected from the sites of lowland and medium altitude of Bako Tibe district of West Showa zone.

\section{MATERIALS AND METHODS}

\section{Apparatus and Glassware}

A stainless steel cutter, drying oven (DHG-9070A), mortar and pestle, $0.5 \mathrm{~mm}$ stainless steel sieve, electronic analytical balance with 0.0001 sensitivity (AA-200DS, Deriver Instrument Company) micropipette (0-50 $\mu \mathrm{L})$, borosilicate beakers $(100,250 \mathrm{~mL})$, hot plate (Glory dial 1$5)$, volumetric flasks $(50,100$ and $1000 \mathrm{~mL})$, Whatman filter paper (No. 42), funnels, capped glass bottles (50 $\mathrm{mL}$ ), flame atomic absorption spectrophotometer (SL194, Double beam AAS, Elico) and flame photometer (CL 378, Elico) were used.

\section{Chemicals and Reagents}

$\mathrm{HNO}_{3}\left(65-68 \%\right.$, Uni-Chem ${ }^{\circledR}$ Chemical reagents, India), $\mathrm{HClO}_{4}\left(70-72 \%\right.$, Uni-Chem ${ }^{\circledR}$ Chemical reagents, India), extra pure hydrogen peroxide $\mathrm{H}_{2} \mathrm{O}_{2}\left(30 \%\right.$, Uni-Chem ${ }^{\circledR}$ Chemical reagents), aqua-regia $\left(1: 3, \mathrm{HNO}_{3}: \mathrm{HCl}\right), \mathrm{HCl}$ (35-38\%, LR, s.d.fine-cHEM LimTEd, MUMBAI) and sucrose, $\mathrm{C}_{12} \mathrm{H}_{22} \mathrm{O}_{11}$ (HIMEDIA ${ }^{\circledR}$, A.R.), stock standard solutions (1000 ppm) prepared in $20 \mathrm{~mL} 1: 1 \mathrm{HNO}_{3}$ for $\mathrm{Cu}$ metal diluted to $1 \mathrm{~L}, 17 \mathrm{~mL} 1: 1 \mathrm{HCl}$ for $\mathrm{Zn}$ and Fe diluted to $1 \mathrm{~L}$ and distilled water (boiled for 30 minutes) were used.

\section{Stock and Working Intermediate Metal Standard Preparation}

The stock standard solutions of each of the metals of interest were prepared at the concentrations of $1000 \mathrm{mg}$ $\mathrm{mL}^{-1}$. The working intermediate metal standard solutions (100 $\mathrm{m} \mathrm{mL} \mathrm{m}^{-1}$ each) were prepared by diluting $10 \mathrm{~mL}$ of $1000 \mu \mathrm{g} \mathrm{mL}^{-1}$ individual metal stock standard solutions with distilled water (boiled for 30 minutes) to a $100 \mathrm{~mL}$ volume.

\section{Calibration Metal Standard Solutions}

A blank and five calibration standard solutions of different concentration levels were prepared for each metal from the respective working intermediate standard solutions $\left(100 \mu \mathrm{g} \mathrm{m}^{-1}\right)$. The metal concentrations include $1.5,2.5,3.5,4.5,5.5 \mathrm{\mu g} \mathrm{mL}^{-1}$ for $\mathrm{Cr} ; 0.25,0.5,0.75,1.0$ $1.25 \mathrm{\mu g} \mathrm{mL}^{-1}$ for $\mathrm{Cd}$; $1.0,2.0,3.0,4.0,5.0 \mathrm{\mu g} \mathrm{mL}^{-1}$ for $\mathrm{Cu}$; $1.0,1.75,2.5,3.25,4.0 \mu \mathrm{g} \mathrm{mL}^{-1}$ for $\mathrm{Mn}$; and $0.5,1.0,2.0$, 4.0, 8.0 $\mathrm{\mu g} \mathrm{mL}^{-1}$ for $\mathrm{Fe}$ and $\mathrm{Zn}$. These calibration standard concentrations were within the working linear range of the instrument used for analysis. Beginning with the blank and working toward the highest standard, the solutions were aspirated and the readings were recorded.
Sci. Technol. Arts Res. J., Oct-Dec 2013, 2(4): 20-26

\section{Spiking Metal Standard Mixture Solution}

A standard mixture solution containing all the metals of interest at varying concentrations $(\mathrm{K}$ and $\mathrm{Na}=80, \mathrm{Mn}=$ 40, $\mathrm{Cu}$ and $\mathrm{Cr}=50, \mathrm{Fe}$ and $\mathrm{Zn}=60, \mathrm{Cd}=10 \mu \mathrm{mL}^{-1}$ ) was prepared by taking $4,2,2.5,3$ and $0.5 \mathrm{~mL}$ stock standard solutions $\left(1000 \mu \mathrm{g} \mathrm{mL}^{-1}\right)$ respectively in to $50 \mathrm{~mL}$ volumetric flask and filling with distilled water (boiled for 30 minute) to the mark.

\section{Sample Collection, Transportation and Pretreatment}

The purposive sampling technique was used. The $2 \mathrm{~kg}$ each gross samples (a composite sample) of the leaves and stems of $R$. prinoides were collected from the sites of the low-altitude (1500-1670 meters above sea level) and medium-altitude (1670-2000 meters above sea level) of areas Bako Tibe district, latitude of $9^{\circ} \mathrm{N}$ and longitude of $37.166667^{\circ} \mathrm{E}$ in January, 2013 G.C.

From the gross samples, sub-samples of $500 \mathrm{~g}$ each from each sample sites were placed in the labeled polyethylene plastic bags and brought to Ambo University chemistry laboratory for further pretreatment and analysis. The samples were further powdered by making use of mortar and pestle and sieved with $0.5 \mathrm{~mm}$ sieve. Finally, $0.5 \mathrm{~g}$ aliquot was taken from each sample for digestion and analysis.

\section{Determination of Moisture Correction Factor of Stem and Leaf Samples}

To determine the moisture content of stem and leaf samples of $R$. prinoides collected from the two sampling areas, the samples were first grounded, sieved through a $0.5 \mathrm{~mm}$ stainless sieve and air dried to constant weight for two weeks. Then, the samples were weighed with analytical electronic balance to record the initial weight. The samples were re-weighed and re-dried until they give constant mass after oven drying at $80{ }^{\circ} \mathrm{C}$ for two days $(24$ $\mathrm{hrs}$ ) and the moisture contents were determined from the differences and the corresponding moisture correction factor (mcf) for analytical results or the multiplication factor for the amount of sample to be weighed for analysis was calculated (Haimanot, 2011).

\section{Optimization of Digestion Procedure for Leaf and Stem Samples of Rhamnus prinoides}

To prepare a clear colorless leaf and stem sample solutions that were suitable for the analysis using FAAS and flame photometry; the digestion procedures were optimized using different proportions of $\mathrm{HNO}_{3}, \mathrm{HClO}_{4}$ and $\mathrm{H}_{2} \mathrm{O}_{2}$ mixtures by varying the digestion time and temperature.

\section{Quality Assurance/Control \\ Calibration and Continuing Calibration Standard}

The FAAS was calibrated using a blank and five series of working standard solutions of each metal and the continuing calibration standard (CCS) of metal standard solution of mid-point calibration concentration was run to test the accuracy of the analytical instrument calibration with each batch samples and the deviation from the original value was within $\pm 5 \%$ Csuros and Csuros, 2002). The performance of flame photometer for $\mathrm{K}$ and $\mathrm{Na}$ was checked with the freshly prepared standard solutions of the two respective metals at concentrations of $10,30,50$, $70,90 \mathrm{ppm}$ for $\mathrm{K}$ and at 1, 5, 10, $20 \mathrm{ppm}$ for $\mathrm{Na}$ and the corresponding recovered values $9.567 \pm 1.692,31.033 \pm$ 
Ararso Nagari and Alemayehu Abebaw

$1.986,50.067 \pm 0.473,69.633 \pm 0.709$ and $89.267 \pm 1.274$ for $\mathrm{K}$ and $0.983 \pm 0.104,5.033 \pm 0.153,10.133 \pm 0.306,15.333 \pm$ 0.764 and $20.667 \pm 0.862$ for $\mathrm{Na}$ were obtained indicating a good performance of the instrument.

\section{Analysis of Matrix Spike and Matrix Spike Duplicate}

Both matrix spike (MS) and matrix spike duplicate (MSD) were prepared for each sample item by spiking aliquots of $0.5 \mathrm{~g}$ of each leaf and stem samples with 2.5 $\mathrm{mL}$ standards mixture solution giving concentrations of 4.0 $\mu \mathrm{g} \mathrm{mL} \mathrm{m}^{-1}$ for $\mathrm{K}$ and $\mathrm{Na}, 2.5 \mu \mathrm{gL}^{-1}$ for $\mathrm{Cu}$ and $\mathrm{Cr}, 0.5 \mu \mathrm{g}$ $\mathrm{mL}^{-1}$ for $\mathrm{Cd}$ and $3.0 \mu \mathrm{g} \mathrm{mL}^{-1}$ for $\mathrm{Fe}$ and $\mathrm{Zn}$. They were all carried through the same digestion and analysis steps as an un-spiked sample. And the mean recovery values of MS and MSD were used to control overall sample matrixdependent accuracy of the analytical method and their relative percent differences (RPD) were calculated by dividing the difference of the test results with the average of the test results and expressed as percent to continuously assess the corresponding method precision (FAO, 2008).

\section{Precision and Accuracy}

The laboratory precision of the results was assessed by the analysis of laboratory control samples (LCSs, $n=3$ ), laboratory control sample duplicates (LCSD), MS $(n=3)$ and MSD. Precision was expressed as the RPD and relative standard deviation (RSD) of replicate results.

The accuracy of the optimized procedure was evaluated by spiking experiments. This included analysis of the MS $(n=3), M S D$, LCSs $(n=3)$, LCSD and method blanks. Accuracy was expressed as the percent recovery of an analyte that has been spiked to the samples in a known concentration before digestion and subsequent analysis.

\section{Limit of Detection and Quantification}

Method detection limit (MDL) and limit of quantification for each metal of interest were estimated by digesting and analyzing seven replicates of the method blanks with the optimized procedure for the leaf and stem samples.

\section{Laboratory Solvent/Reagent Blanks}

The instrument was run with reagent blanks/calibration blanks in which no sample present to determine the background signal and establish the baseline of an instrument. The observed readings were below the method detection limit indicating no instrumental variations and/or false positives during the measurement process.

\section{Method Blank}

Sucrose was used as matrix since there is no other plant that can serve as the matrix for the leaf and stem samples. The blank which was prepared from the sucrose and any reagents used for the digestion was taken through the entire measurement procedure to detect contamination from reagents, sample handling, and the entire measurement process. The analysis results revealed that there were no readings above the method detection limits of the metals. Hence, it can be concluded that the analytical method was free of overall laboratory contamination.
Sci. Technol. Arts Res. J., Oct-Dec 2013, 2(4): 20-26

\section{Analysis of Laboratory Control Samples}

Triplicates of LCSs prepared from sucrose spiked with the target analyte of known concentration the same to sample spike were analyzed along with each batch of the leaf and stem samples. LCS recoveries and the RSD values of the LCS recoveries values for each metal of interest were calculated and used to control overall analytical method accuracy and precision, respectively which were independent of sample matrix effects (Csuros and Csuros, 2002; Miller and Miller, 2010).

\section{Analysis of Stem and Leaf of $\boldsymbol{R}$. prinoides Samples for Metal Levels}

Five replicate analyses were carried out on each sample for the determinations of $\mathrm{Na}$ and $\mathrm{K}$ with flame photometry and $\mathrm{Cu}, \mathrm{Mn}, \mathrm{Cr}, \mathrm{Cd}, \mathrm{Fe}$ and $\mathrm{Zn}$ with FAAS; and the concentrations of $\mathrm{Ca}$ and $\mathrm{Mg}$ were determined by complexometric EDTA titration with the procedure given in FAO (Haimanot, 2011).

\section{Statistical Analysis}

The metal level of each $R$. prinoides samples were analysed by FAAS, FAES and titration. During the processes of sample preparation and analysis a number of random errors may be introduced in each aliquot and in each replicate measurement. The variation in means of the analytes of samples collected from the two sites was tested by using T-test of SPSS Version20 Software to test whether the source for variation was from experimental procedure or heterogeneity among the samples.

\section{RESULTS AND DISCUSSIONS}

Moisture Correction Factor of Stem and Leaf Samples

The moisture content of the four samples of air dried $R$. prinoides was $2.582-3.409 \%$. Therefore, the air dried gesho cultivated in lowland and medium altitude areas of Bako has comparable moisture content with the value 2.5$14.4 \%$ reported for typical analysis of lumber (Simpson, 1999).

\section{Optimization of Digestion Procedures for Leaf and Stem Samples}

From the optimized procedures, the mixture of $2.5 \mathrm{~mL}$ $\mathrm{HNO}_{3}, 1 \mathrm{~mL} \mathrm{HClO} 4$ and $0.5 \mathrm{~mL} \mathrm{H}_{2} \mathrm{O}_{2}$, digestion time of $120 \mathrm{~min}$ and digestion temperature of $170 \pm 4.397{ }^{\circ} \mathrm{C}$ (at dial 2) were found to be the optimal condition for $0.5 \mathrm{~g} R$. prinoides leaf sample and applied for complete digestion of samples. After digestion, the samples were cooled and diluted to $50 \mathrm{~mL}$.

In the same manner, the optimum conditions $2.5 \mathrm{~mL}$ $\mathrm{HNO}_{3}, 1.5 \mathrm{~mL} \mathrm{HClO}_{4}$ and $1 \mathrm{~mL} \mathrm{H}_{2} \mathrm{O}_{2}$ mixtures, digestion time of $110 \mathrm{~min}$ and digestion temperature of $180 \pm 2.582$ ${ }^{\circ} \mathrm{C}$ (at dial 2.5) were obtained for $0.5 \mathrm{~g} \mathrm{R}$. prinoides stem samples.

\section{Quality Assurance/Control Calibration}

Calibration curves for the various concentration ranges showed good correlation coefficients ranged between 0.996 and 0.999 (Table 3 ), which were all greater than the required limit (0.995) for trace element analysis (US EPA, 2007). This showed that there was good correlation (or relationship) between concentration and absorbance indicating good calibration of the instrument. 
Ararso Nagari and Alemayehu Abebaw

\section{Matrix Spike and Matrix Spike Duplicate Results}

The highest average recovery obtained was $103.409 \%$ (Cu in stem) and the lowest $91.875 \%$ ( $\mathrm{Na}$ in leaf) (Table 2) where all were in the range $80-120 \%$, which is recommended for matrix spike recovery of major element analyses by FAAS (US EPA, 2008). This indicated that the analytical process has provided the required matrixdependant accuracy. Therefore, the method was well applicable for all the matrices and all the results obtained were trustable.

RPD values of MS and MSD obtained ranged between 1.556 ( $\mathrm{K}$ in stem) and 13.451 (Fe in stem) (Table 2) which were in the acceptance limit $(\leq 15 \%)$ (FAO, 2008). This showed that the overall analytical process was less affected by matrix-specific variability and the data generated was in the acceptable quality range.

\section{Method Accuracy}

The percent recoveries of each sample spike $(n=3)$ were determined for each metal as shown in Table 1 and ranged between the highest 99.94 (Cu in stem) and lowest 92.583 ( $\mathrm{Na}$ in leaf), all lied in the acceptable range $(80-120 \%)$ for metal analysis (US EPA, 2008). This
Sci. Technol. Arts Res. J., Oct-Dec 2013, 2(4): 20-26

showed that the analytical method provided results in the required level of accuracy.

\section{Method Precision}

Triplicates of each sample spike were digested and analyzed following the same analytical procedure as samples and, then the RSD of the recovery values were calculated as shown in Table 1 and all were under the required limit $(\leq 15 \%)$ (Csuros and Csuros, 2002). This indicated that the analytical method, which covers digestion and instrumental measurement steps, has provided acceptable repeatability or precision.

\section{Instrument Detection, Method Detection and} Quantification Limits

The instrument detection limits ranged between 0.21 and $0.72 \mathrm{mg} \mathrm{kg}^{-1}$, indicating good sensitivity of the measuring instrument for analyses. The MDL values lied in the range 0.797 ( $\mathrm{Cr}$ in leaf) -4.73 ( $\mathrm{Fe}$ in stem) $\mathrm{mg} \mathrm{kg}^{-1}$ and method quantification limit values 1.76 (Cd in leaf)-11 (Fe in stem) $\mathrm{mg} \mathrm{kg}^{-1}$ (Table 3). All the values were found to be in the required limit (Temminghoff and Houba, 2004). This indicated that the method was well applicable for the determination of the essential and nonessential metals.

Table 1: Recovery and precision test for the optimized procedure from sample spike $(n=3)$

\begin{tabular}{|c|c|c|c|c|c|c|}
\hline Metals & $\begin{array}{c}\text { Sample } \\
\text { type }\end{array}$ & $\begin{array}{c}\text { Conc. in sample } \\
\left(\mu \mathrm{g} \mathrm{mL}^{-1}\right)\end{array}$ & $\begin{array}{c}\text { Amount spiked } \\
\left(\mu \mathrm{g} \mathrm{mL}^{-1}\right)\end{array}$ & $\begin{array}{l}\text { Conc. in spiked } \\
\text { sample }\left(\mu \mathrm{g} \mathrm{mL}^{-1}\right)\end{array}$ & Recovery (\%) & $\begin{array}{l}\text { Precision } \\
\left(\%, \text { RSD }^{*}\right)\end{array}$ \\
\hline \multirow{2}{*}{ K } & Leaf & $129.90 \pm 1.572$ & 4.0 & $133.883 \pm 1.815$ & $99.583 \pm 6.292$ & 6.318 \\
\hline & Stem & $104.467 \pm 0.896$ & 4.0 & $108.273 \pm 0.983$ & $95.167 \pm 2.673$ & 2.809 \\
\hline \multirow{2}{*}{$\mathrm{Na}$} & Leaf & $2.60 \pm 0.520$ & 4.0 & $2.637 \pm 0.520$ & $92.583 \pm 4.544$ & 4.908 \\
\hline & Stem & $6.033 \pm 0.153$ & 4.0 & $10 \pm 0.436$ & $99.167 \pm 12.583$ & 12.689 \\
\hline \multirow{2}{*}{$\mathrm{Cu}$} & Leaf & $28.311 \pm 1.263$ & 2.5 & $30.202 \pm 1.366$ & $95.387 \pm 6.19$ & 4.524 \\
\hline & Stem & $29.483 \pm 0.525$ & 2.5 & $31.515 \pm 0.606$ & $99.94 \pm 4.117$ & 1.923 \\
\hline \multirow{2}{*}{$\mathrm{Mn}$} & Leaf & $10.267 \pm 0.467$ & 2.0 & $12.167 \pm 0.382$ & $95 \pm 4.38$ & 3.139 \\
\hline & Stem & $7.45 \pm 0.721$ & 2.0 & $9.411 \pm 0.651$ & $98.033 \pm 3.71$ & 6.914 \\
\hline \multirow{2}{*}{$\mathrm{Cr}$} & Leaf & $1.487 \pm 0.0231$ & 2.5 & $3.956 \pm 0.0311$ & $98.79 \pm 1.652$ & 0.786 \\
\hline & Stem & $1.065 \pm 0.117$ & 2.5 & $3.538 \pm 0.0544$ & $98.938 \pm 2.595$ & 1.537 \\
\hline \multirow{2}{*}{$\mathrm{Cd}$} & Leaf & $0.022 \pm 0.0076$ & 0.5 & $0.503 \pm 0.025$ & $96.267 \pm 4.202$ & 4.922 \\
\hline & Stem & $0.0133 \pm 0.00497$ & 0.5 & $0.50 \pm 0.0312$ & $97.88 \pm 6.125$ & 6.245 \\
\hline \multirow{2}{*}{$\mathrm{Fe}$} & Leaf & $8.1 \pm 1.153$ & 3.0 & $10.929 \pm 1.1325$ & $94.3 \pm 2.917$ & 10.362 \\
\hline & Stem & $77.733 \pm 11.01$ & 3.0 & $80.604 \pm 11.002$ & $95.7 \pm 2.079$ & 13.649 \\
\hline \multirow{2}{*}{$\mathrm{Zn}$} & Leaf & $10.177 \pm 0.0643$ & 3.0 & $13.128 \pm 0.107$ & $98.389 \pm 1.484$ & 0.818 \\
\hline & Stem & $20.867 \pm 2.61$ & 3.0 & $23.702 \pm 2.534$ & $94.513 \pm 5.331$ & 10.69 \\
\hline
\end{tabular}

RSD $=$ Relative standard deviation

Table 2: Mean \%R and RPD values of metals from MS and MSD; and \%R and RSD values of LCSs analysed along with real samples for method validation.

\begin{tabular}{ccccccccc}
\hline \multirow{2}{*}{ Metals } & \multicolumn{2}{c}{ LCS (\%R, $\mathbf{n = 3}$ ) } & \multicolumn{2}{c}{ LCS (RSD) } & \multicolumn{2}{c}{ MS and MSD $(\% \mathbf{R}, \mathbf{n}=2)$} & \multicolumn{2}{c}{ MS and MSD (RPD) } \\
\cline { 2 - 9 } & Leaf & \multicolumn{1}{c}{ Stem } & Leaf & Stem & \multicolumn{1}{c}{ Leaf } & Stem & Leaf & Stem \\
\hline $\mathrm{K}$ & $94.17 \pm 6.29$ & $96.67 \pm 1.44$ & 6.681 & 1.493 & $100 \pm 8.84$ & $94.88 \pm 3.712$ & 12.5 & 5.534 \\
$\mathrm{Na}$ & $90.83 \pm 7.64$ & $91.67 \pm 8.04$ & 8.408 & 8.767 & $91.88 \pm 6.19$ & $92.5 \pm 7.071$ & 9.524 & 10.811 \\
$\mathrm{Cu}$ & $98.55 \pm 6.17$ & $97.41 \pm 7.01$ & 6.256 & 7.194 & $91.95 \pm 3.61$ & $103.41 \pm 3.75$ & 5.128 & 1.905 \\
$\mathrm{Mn}$ & $100.07 \pm 5.73$ & $96.65 \pm 6.32$ & 5.721 & 6.537 & $94.88 \pm 6.19$ & $97 \pm 4.596$ & 6.186 & 8.978 \\
$\mathrm{Cr}$ & $98.26 \pm 2.5$ & $99.69 \pm 1.23$ & 2.55 & 1.235 & $98.15 \pm 1.74$ & $100.1 \pm 2.317$ & 1.556 & 2.198 \\
$\mathrm{Cd}$ & $98.6 \pm 4.06$ & $100.6 \pm 3.86$ & 4.12 & 3.834 & $101.3 \pm 2.12$ & $96.2 \pm 4.243$ & 9.428 & 12.121 \\
$\mathrm{Fe}$ & $99.75 \pm 3.76$ & $96.71 \pm 0.68$ & 3.77 & 0.71 & $98.5 \pm 8$ & $98.617 \pm 7.13$ & 9.839 & 13.451 \\
$\mathrm{Zn}$ & $99.72 \pm 5.12$ & $96.598 \pm 1.68$ & 5.13 & 1.74 & $94.75 \pm 0.15$ & $92.07 \pm 0.632$ & 1.59 & 4.015
\end{tabular}

${ }^{*} \mathrm{LCS}=$ laboratory control samples, \%R'= percent recovery, RSD = relative standard deviation, MS $=$ matrix spike, MSD $=$ matrix spike duplicate, $\mathrm{RPD}^{*}=$ relative percent difference 
Table 3: Instrument detection limit (IDL), method detection limit (MDL), method quantitation limit (MQL) and correlation coefficients of calibration curves for metals determined in stem and leaf samples of $R$. prinoides.

\begin{tabular}{|c|c|c|c|c|c|c|c|}
\hline \multirow{2}{*}{ Metals } & \multirow{2}{*}{$\begin{array}{c}\text { Correlation } \\
\text { coefficient of } \\
\text { calibration curves }\left(r^{2}\right)\end{array}$} & \multirow{2}{*}{$\begin{array}{c}\text { Calibration } \\
\text { equation }\end{array}$} & \multirow{2}{*}{$\begin{array}{c}\text { IDL } \\
\left(\mathrm{mg} \mathrm{kg}^{-1}\right)\end{array}$} & \multicolumn{2}{|c|}{ MDL $\left(\mathrm{mg} \mathrm{kg}^{-1}\right)$ for } & \multicolumn{2}{|c|}{ MQL (mg kg ${ }^{-1}$ ) for } \\
\hline & & & & Leaf & Stem & Leaf & Stem \\
\hline $\mathrm{K}$ & - & - & 0.72 & 3.97 & 3.60 & 7.09 & 6.28 \\
\hline $\mathrm{Na}$ & - & - & 0.40 & 3.11 & 2.01 & 7.02 & 3.57 \\
\hline $\mathrm{Cu}$ & 0.999 & $Y=0.033 X+0.003$ & 0.62 & 3.28 & 3.00 & 5.28 & 4.85 \\
\hline $\mathrm{Mn}$ & 0.996 & $Y=0.008 X+0.003$ & 0.15 & 1.60 & 1.25 & 3.95 & 3.34 \\
\hline $\mathrm{Cr}$ & 0.999 & $Y=0.013 X+0.002$ & 0.13 & 0.73 & 0.60 & 1.89 & 1.59 \\
\hline $\mathrm{Cd}$ & 0.999 & $Y=0.082 X+0.002$ & 0.06 & 0.50 & 0.51 & 1.02 & 1.05 \\
\hline $\mathrm{Fe}$ & 0.998 & $Y=0.015 X+0.005$ & 0.59 & 1.20 & 2.30 & 3.08 & 3.97 \\
\hline $\mathrm{Zn}$ & 0.997 & $Y=0.049 X+0.020$ & 0.44 & 1.24 & 2.08 & 3.37 & 3.69 \\
\hline
\end{tabular}

\section{Laboratory Control Samples Result}

The percent recovery values of LCS lied in the range 90.833 ( $\mathrm{Na}$ in leaf)-100.6\% (Cd in stem) and their relative standard deviations 0.71 ( $\mathrm{Fe}$ in stem)-8.767 ( $\mathrm{Na}$ in stem) (Table 2). And all the values were found under standard control limits $80-120 \%$ for LCS recovery, and $\leq 15 \%$ for RSD (Csuros and Csuros, 2002). This showed that the method used for the study has provided the required level of accuracy and precision throughout the analytical process.

\section{Metals in the Leaf Samples}

Levels of selected essential and nonessential metals were determined in two $0.5 \mathrm{~g}$ leaf samples of $\mathrm{R}$. prinoides (of lowland and medium altitude areas) and the data of total concentrations of the metals in the leaf samples studied were summarized in Table 4.

Table 4: Average concentration (mean $\pm \mathrm{SD}^{*}, \mathrm{n}=5, \mathrm{mg} \mathrm{kg}^{-1}$ air dry weight) of metals in stem and leaf samples of $R$. prinoides.

\begin{tabular}{|c|c|c|c|c|}
\hline \multirow{2}{*}{ Metals } & \multicolumn{2}{|c|}{ Leaf ( $\mathrm{mg} \mathrm{kg}^{-1}$ air dry weight) } & \multicolumn{2}{|c|}{ Stem (mg kg ${ }^{-1}$ air dry weight) } \\
\hline & Lowland & Medium altitude & Lowland & Medium altitude \\
\hline $\mathrm{K}$ & $12927.3 \pm 346.915$ & $11651.3 \pm 333.437$ & $10239.54 \pm 386.225$ & $8855.543 \pm 269.944$ \\
\hline $\mathrm{Na}$ & $226.214 \pm 19.235$ & $320.214 \pm 10.368$ & $308.657 \pm 7.906$ & $413.657 \pm 7.906$ \\
\hline $\mathrm{Ca}$ & $7424 \pm 158.997$ & $11120 \pm 126.491$ & $6144 \pm 190.997$ & $7416 \pm 153.883$ \\
\hline $\mathrm{Mg}$ & $352.34 \pm 13.143$ & $1526.809 \pm 122.978$ & $413.617 \pm 12.638$ & $1210.213 \pm 103.081$ \\
\hline $\mathrm{Cu}$ & $29.10 \pm 3.455$ & $36.978 \pm 6.428$ & $46.338 \pm 4.745$ & $49.913 \pm 5.829$ \\
\hline $\mathrm{Mn}$ & $13.107 \pm 0.28$ & $7.357 \pm 1.976$ & $9.407 \pm 0.259$ & $3.357 \pm 0.198$ \\
\hline $\mathrm{Cr}$ & $1.714 \pm 0.34$ & $1.714 \pm 0.193$ & $2.174 \pm 0.296$ & $2.374 \pm 0.237$ \\
\hline $\mathrm{Cd}$ & BMDL $^{*}$ & BMDL & BMDL & BMDL \\
\hline $\mathrm{Fe}$ & $8.58 \pm 1.23$ & $10.71 \pm 3.98$ & $9.387 \pm 3.37$ & $10.73 \pm 0.101$ \\
\hline $\mathrm{Zn}$ & $3.48 \pm 1.54$ & $7.91 \pm 4.99$ & $16.33 \pm 3.04$ & $18.36 \pm 6.12$ \\
\hline
\end{tabular}

As shown in the table, the mean Potassium concentrations in the leaf samples were $12927.3 \mathrm{mg} \mathrm{kg}^{-1}$ for lowland and $11651.3 \mathrm{mg} \mathrm{kg}^{-1}$ for medium altitude. So, $\mathrm{K}$ concentrations were relatively higher than other metals, which were still below the $\mathrm{FAO} / \mathrm{WHO}$ maximum permissible limit of $1-5 \% \mathrm{~K}$ in plant dry matter (FAO, 2006), indicating no exposure risk to it.

The Sodium concentrations of the leaf samples analyzed were 226.214 and $320.214 \mathrm{mg} \mathrm{kg}^{-1}$ respectively in the lowland and medium altitude areas. These concentrations were below the WHO recommendation on sodium maximum consumption for adults, which is $2 \mathrm{~g}$ sodium/day (WHO, 2012).

The average concentration of Calcium in the leaf samples were $7424 \mathrm{mg} \mathrm{kg}^{-1}$ in the lowland areas and $11120 \mathrm{mg} \mathrm{kg}^{-1}$ in the medium altitude areas. Ca concentration was greater in the leaf sample of the medium altitude areas which was slightly greater than typical concentration in plant dry matter of $0.2-1.0 \%$ (FAO, 2006).

Magnesium concentrations in the leaf samples were found $352.34 \mathrm{mg} \mathrm{kg}^{-1}$ (lowland) and $1526.809 \mathrm{mg} \mathrm{kg}^{-1}$ (medium altitude), which was greater in the leaf sample of the medium altitude areas.
Concentrations of Copper in leaf samples were 29.0995 and $36.978 \mathrm{mg} \mathrm{kg}^{-1}$. The greater concentration of $\mathrm{Cu}$ was the one found in leaf sample of medium altitude areas and both concentrations were below the maximum permissible limit of $40 \mathrm{mg} \mathrm{kg}^{-1}$ dry weight (FAO/WHO, 1995).

Concentration of Manganese in the leaf samples of lowland was $13.107 \mathrm{mg} \mathrm{kg}^{-1}$ and that of medium altitude areas was $7.357 \mathrm{mg} \mathrm{kg}^{-1}$, being lower in leaf samples of medium altitude areas. Both $\mathrm{Mn}$ concentrations were below the tolerable limit of $500 \mathrm{mg} \mathrm{kg}^{-1}$, dry weight (Council of US, 2002). The critical concentration of $\mathrm{Mn}$ is 300-500 ppm dry weight and the estimated safe and adequate daily dietary intake in adults is $11 \mathrm{mg} /$ day (Khan et al., 2008).

Iron was determined in the leaf samples and was found to be 8.58 and $10.71 \mathrm{mg} \mathrm{kg}^{-1}$ in leaf samples of lowland and medium altitude areas, respectively. In the UK, the Guidance Level for supplemental intake of iron is $17 \mathrm{mg} /$ day for adults. The WHO's thresholds for iron adequacy ranges between 0 and $6 \%$ according to age and sex (SACN, 2010). Thus, the concentrations of Fe obtained by this research were in this recommended threshold for Fe. 


\section{Ararso Nagari and Alemayehu Abebaw}

Zinc, analyzed in both leaf samples was 3.48 and 7.91 $\mathrm{mg} \mathrm{kg}^{-1}$ in the case of lowland and medium altitude areas, respectively. The amounts of $\mathrm{Zn}$ were below the US Recommended Daily Allowance (RDA) which is 15 $\mathrm{mg} /$ day for males and $12 \mathrm{mg} /$ day for females and estimated maximum intake of $77 \mathrm{mg} / \mathrm{day}$ (http://www.google.com.et/search?output=search\&sclient $=-$ psyab\&q=Risk+Assessment $\% 2 C+Z i n c+p d f)$.

Chromium was detected in both the leaf samples although at very low concentrations. Its concentration was observed to be $1.714 \mathrm{mg} \mathrm{kg}^{-1}$ in leaf samples of both lowland and medium altitude areas. The daily intake of $\mathrm{Cr}$ 50-200 $\mathrm{mg}$ has been recommended for adults by US National Academy of Sciences (Khan et al., 2008) and the minimum reporting limit for $\mathrm{Cr}$ in tissue is $1 \mathrm{mg} \mathrm{kg}^{-1}$ (US EPA, 2012).

The mean Cadmium concentrations were below method detection limits in leaf and were below the acceptable concentration for food stuff which is around 1 ppm (Khan et al., 2008), indicating no exposure risk to Cd.

Generally, when the distribution of the selected essential and nonessential metals over each leaf sample of $R$. prinoides was observed, they were found to vary in the order: $\mathrm{K}>\mathrm{Ca}>\mathrm{Mg}>\mathrm{Na}>\mathrm{Cu}>\mathrm{Mn}>\mathrm{Fe}>\mathrm{Zn}>\mathrm{Cr}>$ $\mathrm{Cd}$ (BMDL) in leaf samples of lowland areas, $\mathrm{K}>\mathrm{Ca}>$ $\mathrm{Mg}>\mathrm{Na}>\mathrm{Cu}>\mathrm{Zn}>\mathrm{Fe}>\mathrm{Mn}>\mathrm{Cr}>\mathrm{Cd}(\mathrm{BMDL})$ in leaf samples of medium altitude areas.

\section{Metals in the Stem Samples}

The levels of ten metals (four major and six trace) were determined in two stem samples and the results were summarized in Table 4 . This data indicated the concentrations of $\mathrm{K}, \mathrm{Ca}, \mathrm{Mg}, \mathrm{Na}, \mathrm{Cu}, \mathrm{Mn}, \mathrm{Fe}, \mathrm{Zn}$ and $\mathrm{Cr}$ to be $10239.54,6144,413.617,308.657,46.338$, 9.407, $9.387,16.33$ and $2.174 \mathrm{mg} \mathrm{kg}^{-1}$ respectively in the lowland stem samples of $R$. prinoides; and 8855.543 , $7416,1210.213,413.657,49.913,3.357,10.73,18.36$ and $2.374 \mathrm{mg} \mathrm{kg}^{-1}$ respectively in the medium altitude stem samples of $R$. prinoides. The concentrations of all metals were greater in the medium altitude stem samples of $R$. prinoides except that of $\mathrm{K}$ which was greater in the lowland stem samples of $R$. prinoides and of $\mathrm{Fe}, \mathrm{Zn}$ and $\mathrm{Cr}$ which were comparable in both samples. And all the concentrations were under the $\mathrm{FAO}$ WHO maximum permissible limit of typical concentration in plant dry matter $1-5 \%$ for $\mathrm{K}, 0.2-1.0 \%$ for $\mathrm{Ca}, 0.1-0.4 \%$ for $\mathrm{Mg}$, $20-500 \mu \mathrm{g} \mathrm{g}^{-1}$ for Mn, 5-20 $\mathrm{mg} \mathrm{g}^{-1}$ for $\mathrm{Cu}, 50-250 \mathrm{\mu g} \mathrm{g}^{-1}$ for $\mathrm{Fe}, 21-150 \mathrm{\mu g} \mathrm{g}^{-1}$ for $\mathrm{Zn}(\mathrm{FAO}, 2006)$ and the minimum reporting limit $1 \mathrm{mg} \mathrm{kg}^{-1}$ for $\mathrm{Cr}$ in tissue (US EPA, 2012).

Generally, the distributions of the selected essential and nonessential metals in each stem samples of $R$. prinoides, they were in the order of: $\mathrm{K}>\mathrm{Ca}>\mathrm{Mg}>\mathrm{Na}>$ $\mathrm{Cu}>\mathrm{Zn}>\mathrm{Mn}>\mathrm{Fe}>\mathrm{Cr}>\mathrm{Cd}(\mathrm{BMDL})$ in lowland stem samples and $\mathrm{K}>\mathrm{Ca}>\mathrm{Mg}>\mathrm{Na}>\mathrm{Cu}>\mathrm{Zn}>\mathrm{Fe}>\mathrm{Mn}>\mathrm{Cr}$ $>\mathrm{Cd}(\mathrm{BMDL})$ in medium altitude stem samples.

\section{Metal Levels of Lowland Leaf and Stem}

The analyzed selected metal levels of lowland stem and leaf samples of the $R$. prinoides indicated that they were irregularly distributed. The concentration of $\mathrm{K}$ was highest in leaf and lowest in stem. $\mathrm{Na}, \mathrm{Mg}, \mathrm{Cu}, \mathrm{Fe}$ and $\mathrm{Cr}$
Sci. Technol. Arts Res. J., Oct-Dec 2013, 2(4): 20-26

levels were highest in stem, lowest in leaf; $\mathrm{Ca}$ and $\mathrm{Mn}$ were highest in leaf, lowest in stem; $\mathrm{Zn}$ levels were lowest in leaf and highest in stem samples; and Cd levels were below method detection limits in both sample items (Table 4).

\section{Metal Levels of Medium altitude Leaf and Stem}

The distributions of selected essential and nonessential metal levels analyzed in the medium altitude stem and leaf samples of $R$. prinoides were observed to be irregular. The concentration of $\mathrm{K}$ was highest in leaf and lowest in stem. $\mathrm{Na}, \mathrm{Fe}, \mathrm{Zn}$ and $\mathrm{Cu}$ levels were highest in stem, lowest in leaf. Ca was highest in leaf, lowest in stem. Concentrations of $\mathrm{Mg}, \mathrm{Mn}$ and $\mathrm{Cr}$ were highest in leaf, lowest in stem and Cd levels were below method detection limits in both sample items (Table 4).

\section{Metal Levels of Leaf and Stem}

The findings of this study were compared with some other related published reports conducted in some other parts of the world with regard to the essential and nonessential metal levels in leaf and stem samples.

The mean levels of $\mathrm{Na}$ and $\mathrm{K}$ in leaf and stem of $R$. prinoides of this study were lower than the one reported by Idris et al. (2011) on nutritional composition of the leaves and stems of ocimum gratissimum in Nigeria. The amounts of $\mathrm{Ca}$ and $\mathrm{Mg}$ in leaf and stem of $R$. prinoides of present study were higher than that obtained by Idris et al. (2011) in Nigeria where as that of $\mathrm{Zn}$ in leaf and stem were slightly lower and $\mathrm{Fe}$ were lower in leaf and greater in stem than the value reported by Idris et al. (2011); and $\mathrm{Ca}$ in leaf was comparable; $\mathrm{Mg}, \mathrm{Mn}, \mathrm{Fe}, \mathrm{Zn}$ and $\mathrm{Cr}$ in leaf was lower and $\mathrm{Cu}$ was slightly greater compared to the results reported by Minaleshewa (2010) on khat here in Ethiopia. The levels of Mn, Fe, Zn and Cd were lower and that of $\mathrm{Cu}$ were higher in leaf than the values in leaf reported by Khattak and Khattak (2011) in Pakistan.

A study conducted here in Ethiopia, investigated the levels of essential and nonessential metals in the leaf and stem of $R$. prinoides cultivated in Ethiopia (Afewerk and Chandravanshi, 2012). The study was confirmed concentrations of $\mathrm{Ca}, \mathrm{Mg}, \mathrm{Cu}, \mathrm{Mn}, \mathrm{Fe}, \mathrm{Zn}, \mathrm{Cr}$ and $\mathrm{Cd}$ to be 6304-22236, 3202-5706, 6.5-73, 8.12-17.9, 47.9$187,12.2-43,5.08-20.6$ and $0.81-3.1$ respectively in leaf and $3601-5675,2635-5528,16.8-233,2.6-3.98,22.0$ 124, 17.4-28.2, ND-16.3 and ND-1.56 respectively in stem. The same trend has been observed in the present study except that of $\mathrm{Ca}$ and $\mathrm{Mn}$ in stem which were somewhat greater; and $\mathrm{Mg}$ and $\mathrm{Fe}$ in both and $\mathrm{Zn}$ in leaf were below this range.

\section{CONCLUSIONS}

A wet acid-digestion method using the mixture of $\mathrm{HNO}_{3}, \mathrm{HClO}_{4}$ and $\mathrm{H}_{2} \mathrm{O}_{2}$ for preparation of leaf and stem samples were optimized, validated and used. The determinations of selected essential and non-essential metal levels ( $\mathrm{K}, \mathrm{Na}, \mathrm{Ca}, \mathrm{Mg}, \mathrm{Cr}, \mathrm{Cu}, \mathrm{Zn}, \mathrm{Fe}, \mathrm{Mn}$ and $\mathrm{Cd}$ ) in the samples were made by flame photometer, flame atomic absorption spectrophotometer and complexometric titration with EDTA. The quality of the analytical data generated and general laboratory performance were continuously monitored and verified through the analyses of several quality control parameters including CCS, LCSs, MS, MSD, method blank and laboratory 


\section{Ararso Nagari and Alemayehu Abebaw}

solvent/reagent blanks. The analyses results ensured that the laboratory systems such as instrumentation, sample preparation, analysis and data acquisition were all operating within acceptable guidelines.

T-test was performed among the leaf and stem samples of the two sites separately to assess whether the essential and nonessential metals were distributed in significantly different concentrations or not. The test results showed that there were significant differences $(p<$ 0.05 , at $95 \% \mathrm{CL}$ ) in the concentrations of all metals of interest among the analyzed leaf and stem samples except $\mathrm{Fe}$ and $\mathrm{Zn}$ (in leaf and stem) and $\mathrm{Cu}$ and $\mathrm{Cr}$ (in stem). The metals such as $\mathrm{K}, \mathrm{Ca}, \mathrm{Mg}, \mathrm{Na}$ and $\mathrm{Cu}$ were generally found in higher concentrations than the rest metals in all of the samples. However, in comparison with the recommended maximum permissible limits, the levels of all metals of interest were in the similar range of the $\mathrm{FAO} / \mathrm{WHO}$ or EPA tolerable limits which means that they were found under the safe limits. This indicated that there was no risk of exposure through the use of this plant in the case of the two sampling areas. The metal levels investigated in leaf and stem samples were also found to be comparable with other similar studies conducted over different parts of the world.

The variations of the metal concentrations in the leaf and stem may be ascribed to: nature of the leaf and stem (i.e., the differences in physiological properties of metal uptake that varies from site to site, exposure surface area and plant age); the physical and chemical nature of the soil where the plant grew (cation exchange capacity, organic matter content and soil $\mathrm{pH}$ ); atmospheric deposition of the metals (which may be influenced by innumerable environmental factors such as temperature, moisture and $\mathrm{pH}$ ) (Kalra, 1998). In short, leaves and stems are good sources of a healthy diet; and they are not exposure routes to some metal contaminations under the current existing situation.

\section{ACKNOWLEDGMENTS}

The authors would like to express the deepest thanks to Ambo University for the financial support and laboratory facility.

\section{REFERENCES}

Afewerk, G., Chandravanshi, B.S. (2012). Levels of Essential and Non-essential Metals in Rhamnus prinoides (Gesho) Cultivated in Ethiopia. Bulletin of the Chemical Society of Ethiopia 26(3): 329-342.

Berhanu, A.M., Teshome, K. A. (1995). Bitter Principle of Rhamnus prinoides and Other Constituents of the Leaves. Bulletin of the Chemical Society of Ethiopia 9(2): $107-114$

Council of US. (2002). Guide Lines on Metals and Alloys Used as Food Contact Materials.

Csuros, M., Csuros, C. (2002). Environmental sampling and analysis for metals. CRC Press, USA.
Sci. Technol. Arts Res. J., Oct-Dec 2013, 2(4): 20-26

FAO. (2006). Plant Nutrition for Food Security. A Guide for Integrated Nutrient Management by Roy RN. FAO 16.

FAO. (2008). Guide to Laboratory Establishment for Plant Nutrient Analysis by Roy RN. FAO Fert PI Nut Bul 19.

FAO/WHO. (1995). Codex General Standard for Contaminants and Toxins in Food and Feed (CODEX STAN 193-1995).

Hailemichael, A., Berhanu, A.M., Merhatibeb, B. (2007). Electrochemical Behaviour and Voltammetric Determination of Geshoidin and its Spectrophotometric and Antioxidant Properties in Aqueous Buffer Solutions. Bulletin of the Chemical Society of Ethiopia 21(2): 189204.

Haimanot, A. (2011). Isolation and Characterization of the Dominant Yeast in the Traditional beverages of Ethiopia; Tella and Tej. M.sc. Thesis, Addis Ababa University.

Idris, S., Iyaka, Y.A., Ndamitso, M.M., Paiko, Y.B. (2011). Nutritional Composition of the Leaves and Stems of Ocimum Gratissimum. Journal of Emerging Trends in Engineering and Applied Sciences 2(5): 801-805.

Kalra, Y.P. (1998). Handbook of Reference Methods for Plant Analysis. Taylor \& Francis Group, Boca Raton, USA.

Khan, Sh.A., Khan, L., Hussain, I., Marwat, K.B., Akhtar, N. (2008). Profile of Heavy Metals in Selected Medicinal Plants. Pakistan Journal of Weed Science Research 14(1-2): 101-110.

Khattak, M.I., Khattak, M.I. (2011). Study of Heavy Trace Metals in Some Medicinal-Herbal Plants of Pakistan. Pakistan Journal of Botony 43(4): 2003-2009.

Miller, N.J., Miller, C.J. (2010). Statistics and Chemometrics for Analytical Chemistry, $6^{\text {th }}$ ed. Pearson Education Limited, UK.

Minaleshewa, A. (2010). Concentration Levels of Essential and Non-essential Metals in Ethiopian Khat (Catha edulis Forsk). Biological Trace Element Research 138: 316-325.

SACN. (2010). Iron and Health. TSO (The Stationery Office), London.

Simpson, W.T. (1999). Drying and Control of Moisture Content and Dimensional Changes. Chapter 12.

Temminghoff, E..J., Houba, V.J. (2004). Plant Analysis Procedures Second Edition. Kluwer Academic Publishers, Netherlands.

US EPA. (2007). Solutions to Analytical Chemistry Problems with Clean Water Act Methods. EPA 821-R-07-002, Washington, DC

US EPA. (2008). National Functional Guidelines for Superfund Organic Methods Data Review. USEPA-540R08-01, Washington, DC.

US EPA. (2012). Laboratory Operations and Quality Assurance Manual. Analytical Support Branch, Athens, Georgia 30605-2700.

WHO. (2012). Guideline: Sodium Intake for Adults and Children. Geneva. 